\title{
Microbial mats as shelter microhabitat for amphipods in an intermittent karstic spring
}

\author{
Petar Žutinić $^{1, *}$, Ines Petrić ${ }^{2}$, Sanja Gottstein ${ }^{1}$, Marija Gligora Udovič ${ }^{1}$, Koraljka Kralj Borojević ${ }^{3}$, \\ Jasmina Kamberović $^{4}$, Anamarija Kolda ${ }^{2}$, Anđelka Plenković-Moraj ${ }^{1}$ and Ivančica Ternjej ${ }^{1}$ \\ ${ }^{1}$ Department of Biology, Faculty of Science, University of Zagreb, Rooseveltov trg 6, 10000 Zagreb, Croatia \\ ${ }^{2}$ Division for Marine and Environmental Research, Ruđer Bošković Institute, Bijenička cesta 54, 10000 Zagreb, Croatia \\ 3 Minnesota Drive, Great Sankey, WA5 3SY Warrington, UK \\ ${ }^{4}$ Department of Biology, Faculty of Natural Sciences and Mathematics, University of Tuzla, Univerzitetska 4, 75000 Tuzla, Bosnia and \\ Herzegovina
}

\begin{abstract}
Microbial mats represent complex communities where cyanobacteria and diatoms as key organisms provide shelter for diverse assemblages of aquatic invertebrates, like the small stygophilous amphipod Synurella ambulans. Studies addressing such communities in the karst springs have rarely examined springheads, and have ignored intermittent springs. During high flow conditions the stygophilic crustaceans are flushed to the surface of a temporary stream Krčić where microbial mats prevent their drift and enables their successful retreat into underground in the periods of drought. The objective of this study was to characterize the microbial mat community of the Krčić Spring as a shelter for $S$. ambulans during strong current and high water level. Representative samples for diatom and cyanobacterial species identification and composition, as well as the fresh mat material for potential animal activity and cyanobacterial phylogenetic analysis were collected. The most dominant diatom was Achnanthidium minutissimum, whilst Fragilaria capucina, Meridion circulare, Navicula cryptocephala and Nitzschia palea had abundance greater than $0.5 \%$. Morphological observations of cyanobacteria revealed that Phormidium favosum was the most dominant, with Hydrocoleum muscicola as a subdominant. Cyanobacterial phylogenetic relationship revealed two distinct clusters: (i) "Phormidium cluster", confirming morphological observations in both winter and spring samples, and (ii) "Wilmottia cluster", a first report for Croatia and found exclusively in the winter sample. Laboratory observations revealed a small stygophilic amphipod S. ambulans, hiding and feeding inside the pockets of fresh microbial mat. The intermittent Krčić Spring as a predator-free and competitor-free ecosystem provides a spatiotemporal conformity between microbial mat and stygophilous amphipod.
\end{abstract}

Keywords: Microbial mat / cyanobacteria / diatoms / amphipods / karstic spring

Résumé - Le tapis microbien comme microhabitat refuge pour les amphipodes dans une source karstique intermittente. Le tapis microbien représente des communautés complexes où les cyanobactéries et les diatomées, en tant qu'organismes clés, abritent divers assemblages d'invertébrés aquatiques, comme les petits amphipodes stygophiles Synurella ambulans. Les études portant sur ces communautés dans les sources karstiques ont rarement examiné ces têtes de ruisseaux et ont ignoré les sources intermittentes. Dans les conditions d'écoulement fort, les crustacés stygophiles sont chassés à la surface d'un ruisseau temporaire Krčić où les tapis microbiens empêchent leur dérive et permettent leur retrait dans le sous-sol en période de sécheresse. L'objectif de cette étude était de caractériser la communauté du tapis microbien de la source Krčić comme abri pour $S$. ambulans lors de forts courants et de niveaux d'eau élevés. La diatomée la plus dominante était Achnanthidium minutissimum, tandis que Fragilaria capucina, Meridion circulare, Navicula cryptocephala et Nitzschia palea avaient une abondance supérieure à $0.5 \%$. Des échantillons représentatifs ont été prélevés pour l'identification et la composition des espèces de diatomées et de cyanobactéries, ainsi que de la matière organique du tapis servant à l'activité animale potentielle et pour l'analyse phylogénétique des cyanobactéries. Les observations morphologiques des cyanobactéries ont

\footnotetext{
*Corresponding author: petar.zutinic@biol.pmf.hr
} 
révélé que Phormidium favosum était le plus dominant, avec Hydrocoleum muscicola comme sousdominant. L'étude phylogénétique cyanobactérienne a révélé deux groupes distincts: (i)"groupe de Phormidium", confirmant les observations morphologiques dans des échantillons hivernaux et printaniers, et (ii)"groupe de Wilmottia", une première observation pour la Croatie trouvé exclusivement dans l'échantillon hivernal. Les observations en laboratoire ont révélé qu'un petit amphipode stygophile $S$. ambulans se cachait et se nourrissait dans les poches du tapis microbien. La source Krčić intermittente en tant qu'écosystème sans prédateurs et sans concurrents assure une conformité spatio-temporelle entre le tapis microbien et l'amphipode stygophilique.

Mots-Clés : Tapis microbien / cyanobactérie / diatomée / amphipode / source karstique

\section{Introduction}

Microbial mats are structurally complex communities composed of physiologically and ecologically diverse microorganisms adapted to gradients of light and nutrient accessibility. They are present in very diverse, often extreme environments with limited or even minimal top-down controls, like ephemeral and intermittent streams and springs (Stal and Caumette, 1994; Stanish et al., 2013). Microbial mats can form dense micrometer-scale communities in which the full plethora of microbial metabolism can be present, usually consisting of filamentous, entangled organisms that produce a macroscopic 'mat-like' structure. These structures exhibit great variety in morphology and composition and may include diverse biofilms of immobilized microorganisms (Bauld, 1984). Cyanobacteria and diatoms are emphasized as the key organisms comprising microbial mats in spring habitats (Esposito et al., 2006; Stal, 2012; Cantonati et al., 2012, 2015, 2016), where these prokaryotic-eukaryotic interactions play an important role in microbial mat development by enabling significant photosynthetic activity (Elster and Komárek, 2003) and nutrient cycling and acquisition (Gooseff et al., 2004; McKnight et al., 2004; Mueller and Vincent, 2006). Their remarkable adaptability, through which they can overcome the extremity of environmental conditions prevailing in many carbonate-rock springs, makes them one of the key components in terms of ecology, management and conservation of spring ecosystems (Cantonati et al., 2015). Taxa populating these habitats must be able to cope with rapid irradiance alterations, high water-level fluctuations and monthslong drought periods. Moreover, a diverse assemblages of aquatic invertebrates, particularly amphipods like the small stygophilous spring dwelling Synurella ambulans (F. Müller, 1846), live on and within the microbial mats (Camacho and Thacker, 2006, 2013; Korpinen et al., 2006; Lévesque et al., 2015).

A complex geological history of Croatian Dinaric karst manifests through formation of specific features, like welldeveloped underground drainage system, strong interactions between circulation of surface and groundwater, presence of unpredictable conduits, fissures and cavities beneath the ground, unexpected connections of water, changes of underground flow path over time, all of which shape a pronouncedly heterogeneous hydrological, hydrogeological, morphological, physicochemical and biological conditions in karst springs (Bonacci, 1993, 2015). The majority of water input into karst spring systems is caused by rainfall, which reaches groundwater via infiltration through karst aquifers.
Variations in precipitation induce rapid and pronounced oscillations of groundwater, strongly affect spring flow and cause fluctuations in discharge volume, thus making catchment boundaries of springs extremely time-variant (Hao et al., 2012; Bonacci, 2015). Karst spring discharges reflect periods of poor or abundant precipitations due to specific recharge conditions and the locally prevalent climate regime (Bonacci, 2015; Fiorillo et al., 2015). In such conditions streamflow regime is recognized as the principal variable affecting the success and distribution of aquatic biota (Meyer and Meyer, 2000; Meyer et al., 2003; Konrad et al., 2008). Limited knowledge of the effects of temporary seasonal drying of karst springs on stream biota introduces numerous questions when comparing biological integrity of these specific habitats to perennially flowing streams (Reiss and Chifflard, 2015).

There is a paucity of information on the adaptations of various organisms to temporary streamflows and their use of microbial mats during these stressful conditions (McDonough et al., 2011; Robson et al., 2011). Most studies addressing cyanobacterial and diatom communities in karst springs have examined mostly perennial streams, rarely springheads, and have ignored intermittent springs (Cantonati et al., 2012, 2016). Their ecological role as the food source and shelter for freshwater invertebrates is still poorly understood (Camacho and Thacker, 2013; Lévesque et al., 2015). During high flow conditions specimens of the stygophilic amphipod $S$. ambulans are flushed to the surface of a temporary stream Krčić where they can be retained by the microbial mat and moss, thus preventing their drift and facilitating their successful retreat into underground in the periods of drought. The objective of this study was to characterize the microbial mat community in the karstic stream Krčić and its role as a feasible alternative shelter for the subterranean stygophilic crustacean $S$. ambulans during two events: (i) high water level with fast streamflow, and (ii) water level decrease preceding drought.

\section{Materials and methods}

\subsection{Study area}

Krčić is a small intermittent stream situated in the middle of Dinaric karst of the southern Croatia, confined mostly to the External Dinarides, which consists predominantly of Triassic, Jurassic and Cretaceous limestones and dolomites (Bonacci et al., 2006; Hajna et al., 2010). The study area falls within a continental climate influenced by the mid-Mediterranean climate with the average annual temperature of $13^{\circ} \mathrm{C}$. The 


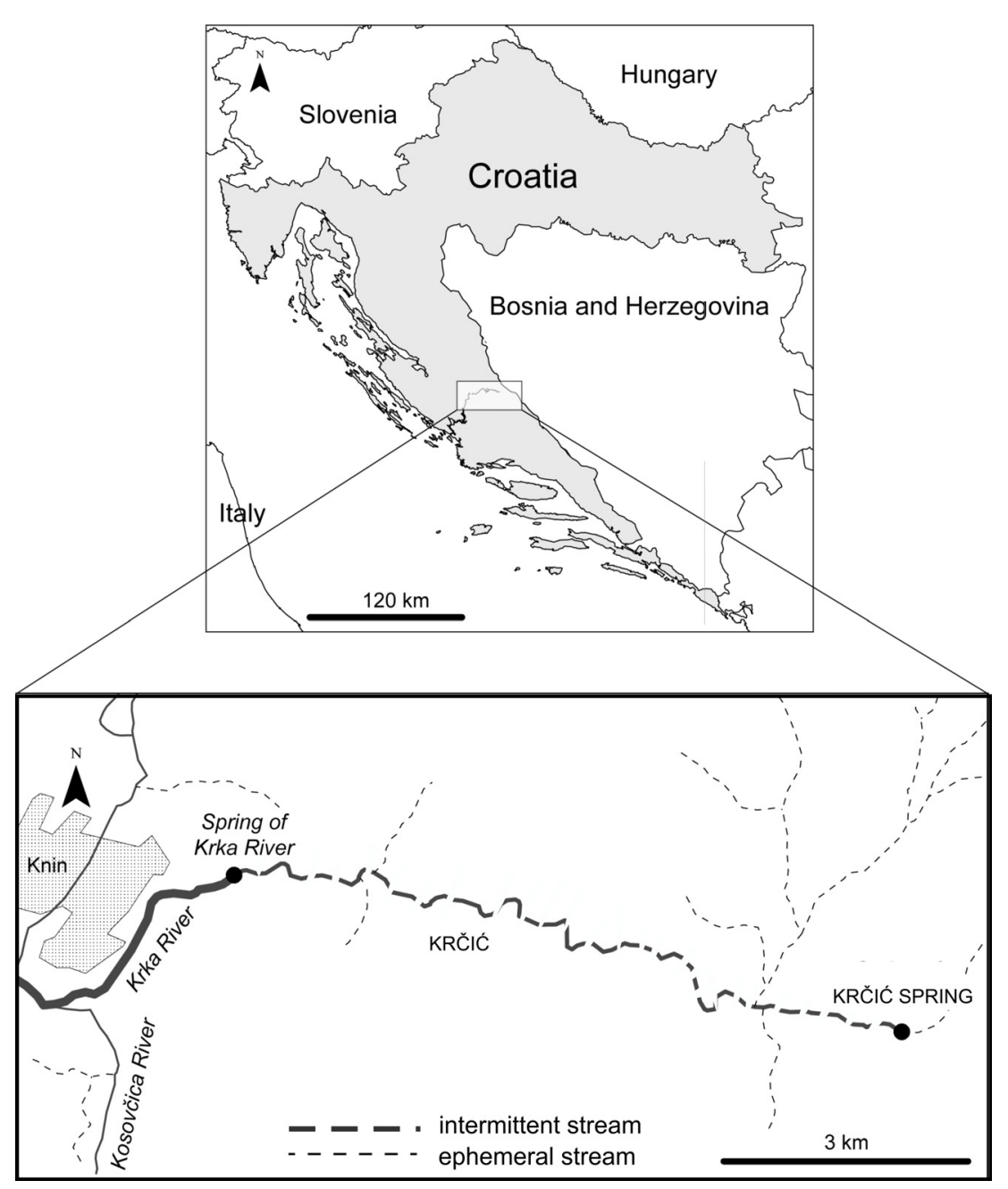

Fig. 1. Map of the investigated area.

summers are hot, with maximum temperature above $30^{\circ} \mathrm{C}$, whilst winters are cold with temperatures as low as $-10^{\circ} \mathrm{C}$. The catchment area of Krčić covers $157 \mathrm{~km}^{2}$ with the surface flow of $10.5 \mathrm{~km}$ from the springhead to the waterfall in the Krka River (Bonacci et al., 2006). The spring and the mouth of the river lie between latitudes $44^{\circ} 1^{\prime} 32^{\prime \prime} \mathrm{N}$ and $44^{\circ} 2^{\prime} 31^{\prime \prime} \mathrm{N}$ and longitudes $16^{\circ} 19^{\prime} 53^{\prime \prime} \mathrm{E}$ and $16^{\circ} 14^{\prime} 7^{\prime \prime} \mathrm{E}$, respectively (Fig. 1). Strong river bed karstification causes significant water losses along the stream causing alternating surface and subsurface flow (Bonacci, 1987, 1993; Bonacci et al., 2006). Krčić functions as a descending karstic spring (Jukić and DenićJukić, 2006) and dries up regularly every year from June to September, usually when springwater discharge of Krka River (below the mouth of Krčić) drops below $4.20 \mathrm{~m}^{3} \mathrm{~s}^{-1}$ (Bonacci et al., 2006). However, in 2014 it retained water for the entire year because of exceptionally rainy summer (Fig. 2).

The diverse rheocrene Krčić Spring has multiple spheres of discharge rate over time due to groundwater emerges on the bottom, and along the edges of the springhead as a fast-flowing spring runs. The spring is not shaded by trees and the habitats are well preserved, although arteficial barriers of the 18th century mill building are situated $100 \mathrm{~m}$ downstream of the springhead.

\subsection{Specimen collection and identification}

Representative samples of the microbial mat for diatom and cyanobacterial species identification and composition were collected during two field trips in winter (February) and spring (May) of 2014 from the springhead of the Krčić stream. Months were selected based on their hydrologic conditions. February is characterized by high water level accumulating from precipitation and snowmelt. May is distinguished by a strong decrease in streamflow usually followed by a months-long drought period (Fig. 2). Algae were brushed and scraped from the stone surface $\left(3 \times 3 \mathrm{~cm}^{2}\right)$ and rinsed into a sample jar. Samples were preserved with a buffered $4 \%$ formaldehyde solution. Diatom samples were cleaned following Hendey (1964). Acids were neutralised with distilled water until $\mathrm{pH}$ reached 7. Cleaned valves were mounted in Naphrax diatom mountant. Light microscope observations were conducted using an Olympus BX51 Microscope (Olympus, Japan). Diatoms were counted under oil immersion at $1000 \times$ magnification until a minimum of 400 valves have been counted. Identification of diatoms was performed using Krammer and Lange-Bertalot (1986, 1991b), Lange-Bertalot (2001), and Hofmann et al. (2013). For scanning electron microscopy (SEM), part of the clean diatom frustule suspension was filtered 


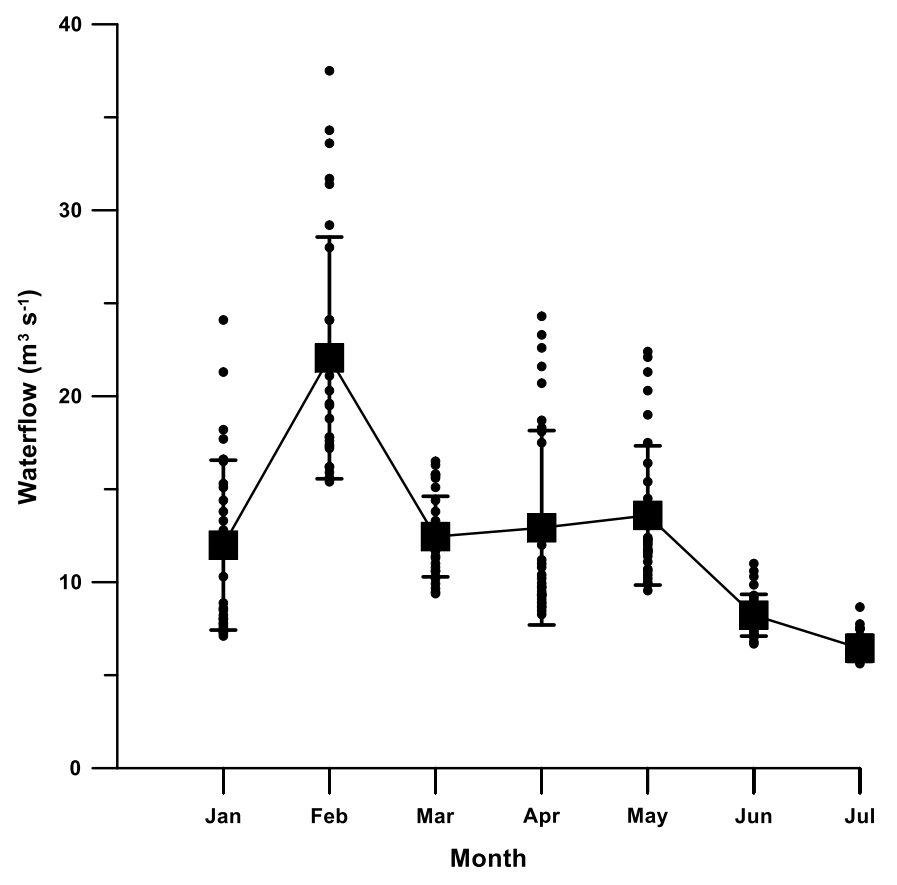

Fig. 2. Waterflow of the lower part of Krčić in the period between January and July 2014 (Meteorological and Hydrological Service, Croatia)

onto Whatman Nucleopore membrane filters (Sigma-Aldrich, USA) with a maximum pore diameter of $0.3 \mu \mathrm{m}$, pieces of which were attached to aluminum stubs after air-drying. The stubs were sputter-coated with $30 \mathrm{~nm}$ of gold and studied using MIRA3 FEG-SEM microscope (Tescan Orsay Holding, Czech Republic) in the Forensic Science Centre Zagreb.

For the morphological analysis of cyanobacterial samples, length and width of at least 30 cells on each trichome were measured under the $1000 \times$ magnification using the BA310 Motic optical microscope (Speed Fair Co. Ltd., China). Identification of cyanobacteria was performed following the most recent literature (Komárek and Anagnostidis, 2005; Palińska et al., 2011; Hašler et al., 2012; Strunecký et al., 2013). Microphotographs were taken with the Optika Pro 3LT camera and processed with Optika Vision Pro Software (Optika Microscopes, Italy).

The fresh mat material, sampled directly at the springhead, was transported to the laboratory for the subtle observations of potential animal activity inside the jelly pockets. Part of fresh mat material was placed into diatom medium (Andersen, 2005) for a few days and sent for DNA extraction.

\subsection{DNA extraction from cyanobacterial mats}

Approximately $100 \mathrm{mg}$ of the fresh mat material preserved in culture media was used as a starting material for nucleic acid extraction. DNA was extracted from winter and spring samples using NucleoSpin Plant II Kit (Macherey-Nagel, Germany) according to the manufacturer instructions with a few modifications. In order to remove the culture media, mat material was first centrifuged $(600 \mathrm{~g}, 15-30 \mathrm{~min})$, followed by resuspension of the obtained cell in TEN buffer (final concentration $50 \mathrm{mM}$ TrisHCl pH 8; $5 \mathrm{mM}$ EDTA; $50 \mathrm{mM}$
Table 1. Primer sequences used for amplification of cyanobacterial 16S rRNA.

\begin{tabular}{|c|c|}
\hline Primer & Sequence $\left(5^{\prime}-3^{\prime}\right)$ \\
\hline CYA106F & CGC ACG GGT GAG TAA CGC GTG A \\
\hline CYA359F & GGG GAA TYT TCC GCA ATG GG \\
\hline CYA781R(a) ${ }^{*}$ & GAC TAC TGG GGT ATC TAA TCC CAT T \\
\hline CYA781R(b) ${ }^{*}$ & GAC TAC AGG GGT ATC TAA TCC CAT T \\
\hline
\end{tabular}

$\mathrm{NaCl})$ with the addition of Sarcosyl (1\%). After $1 \mathrm{~h}$ incubation at the room temperature, pellets were washed 4 times with TEN buffer solution. Each dry pellet, in which $2-5$ small beads were added, was mechanically homogenized to fine powder using FastPrep FP120 Cell Disrupter at $4.5 \mathrm{~m} \mathrm{~s}^{-1}$ for $45 \mathrm{~s}$ (Thermo Savant Bio101, Qbiogene, France). The obtained homogenate was then resuspended in $100 \mu \mathrm{l}$ of TEN buffer solution and incubated at $37^{\circ} \mathrm{C}(15 \mathrm{~min})$ with lysozyme (final concentration $0.5 \mathrm{mg} \mathrm{ml}^{-1}$ ). According to the NucleoSpin Plant protocol, Lysis Buffer PL1 and RNase were added and the sample was incubated at $65^{\circ} \mathrm{C}(30 \mathrm{~min})$. Additional step included the addition of Proteinase $\mathrm{K}$ enzyme to the sample and incubation at $55^{\circ} \mathrm{C}(30 \mathrm{~min})$, followed by a short incubation of the sample at $90^{\circ} \mathrm{C}$ ( $5 \mathrm{~min}$ ) for Proteinase $\mathrm{K}$ inactivation. Samples were then centrifuged $(11000 \mathrm{~g}, 5 \mathrm{~min})$, after which the extraction continued on the NucleoSpin Filter according to manufacturer's instructions (Macherey-Nagel, Germany). The integrity of the DNA obtained at the end of the protocol was checked by electrophoresis on $1 \%$ agarose gel. DNA was quantified at $260 \mathrm{~nm}$ using a BioPhotometer (Eppendorf, Germany).

\subsection{PCR amplification and phylogenetic analysis of cyanobacterial 16S rRNA}

16S rRNA gene fragments were amplified from the DNA by using two primer sets specifically designed to target cyanobacterial 16S rRNA (Nübel et al., 1997). A product of approximately 700 base pairs (bp) was targeted in the 1st PCR and of approx. $450 \mathrm{bp}$ in the 2 nd PCR by using primer set 1 (CYA106F/CYA781R) and primer set 2 (CYA359/CYA781R), respectively. Sequences of the primers used are given in the Table 1. PCR was performed with $100 \mathrm{ng}$ of DNA used as a template under conditions identical to those reported in Srivastava et al. (2007). Cycling conditions were as follows: $94^{\circ} \mathrm{C}$ for $3 \mathrm{~min}$; followed by 35 cycles each consisting of $1 \mathrm{~min}$ denaturation at $94^{\circ} \mathrm{C} ; 1.5 \mathrm{~min}$ annealing at $59^{\circ} \mathrm{C} ; 2 \mathrm{~min}$ elongation at $72^{\circ} \mathrm{C}$; and a final $5 \mathrm{~min}$ elongation at $72^{\circ} \mathrm{C}$. Obtained PCR products were analyzed on agarose gels $(2 \%)$ before being purified from the reaction using gel extraction kit (GenElute Gel extraction kit, Sigma, USA). Subsequently, purified PCR products were cloned into the plasmid vector pGEM-T Easy according to the manufacturer's instructions (Promega, France). Two libraries were established from winter sample (one from 1st PCR and one from 2nd PCR) and two from those samples collected at the spring time (one from 1st PCR and one from 2nd PCR). Clones were picked from different libraries (approx. 20 from each library) and checked for the correct insert size by vector targeted PCR. Diversity 

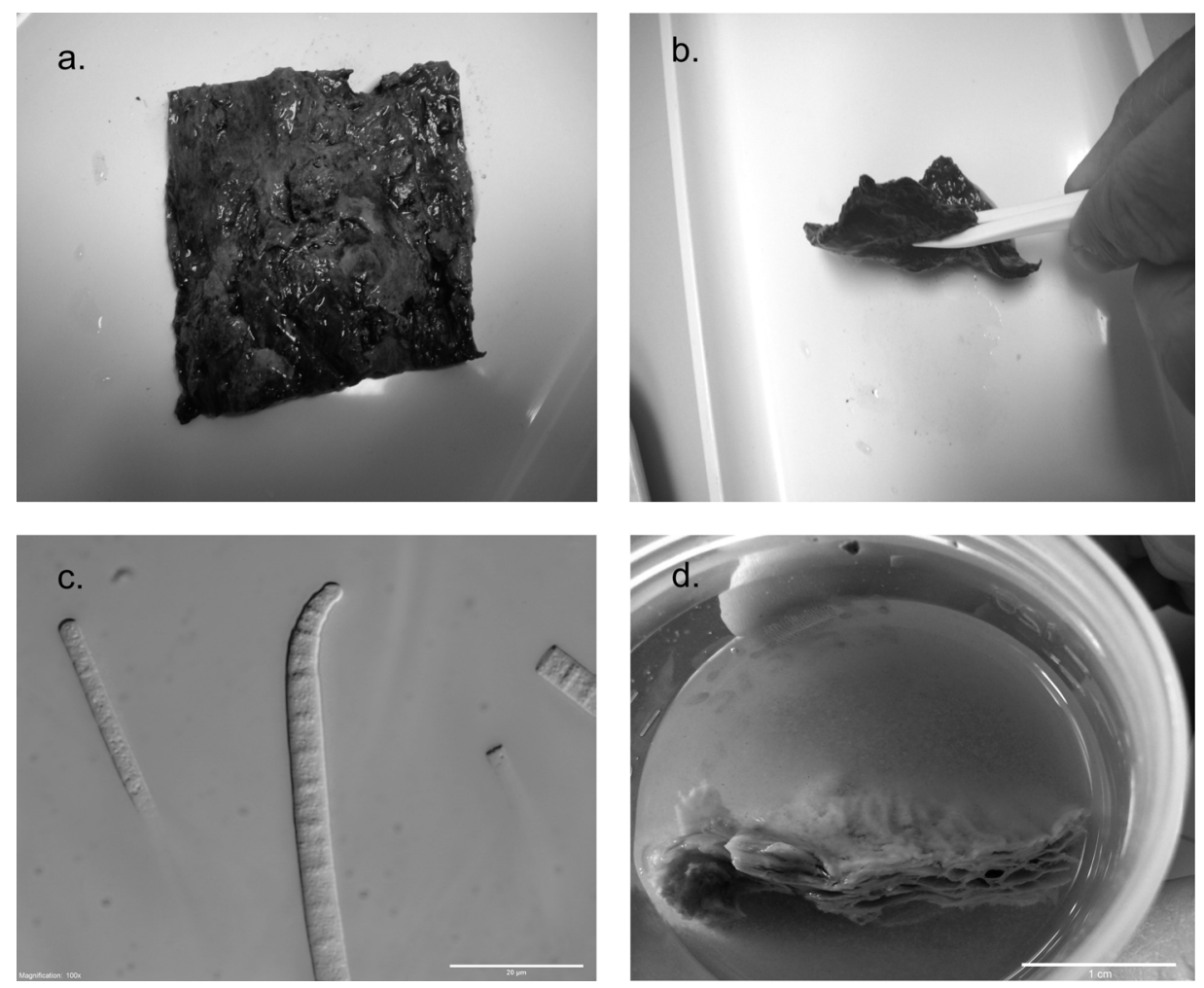

Fig. 3. Components of microbial mats: macroscopic image of microbial mat (a, b); Phormidium favosum (c); visible pockets in microbial mat of Krčić Spring (d).

within 16S rRNA sequences was checked by restriction fragment length polymorphism (RFLP) analysis. Amplified 16S rRNA PCR products were digested with restriction endonucleases AluI (Fermentas, Thermo Fisher Scientific, USA) following manufacturer's instructions. Digested fragments were visualized by running electrophoresis on $3 \%$ agarose gel. Clones showing different RFLP pattern were selected and further subjected to 16S rRNA gene sequencing (Macrogen, Amsterdam) using universal SP6 primer. Forward and complementary sequences were aligned using the Clustal X2 Multiple Sequence Alignment Program (Larkin et al., 2007). Ambiguities and PCR errors were checked manually and the chromatograms were used to make corrections where it was appropriate. The corrected sequences were aligned with sequences from GenBank. 16S rRNA sequences were compared with known nucleotide sequences using the Nucleotide Basic Local Alignment Search Tool (Nucleotide BLAST; http://blast.ncbi.nlm.nih.gov/Blast.cgi). A phylogenetic tree was constructed from multiple alignments drawn by using NJplot software (Perrière and Gouy, 1996) using the neighbour-joining method that included references from GenBank showing highest similarities to our sequences. Nucleotide sequences have been deposited in the Genbank database under the accession numbers KY820663-KY820690.

\section{Results}

Microbial mat was densely developed in the Krčić Spring during high streamflow in both winter and spring samples (Fig. 3). Total biomass of microbial mat was estimated as chlorophyll $a$ concentration. The values of chlorophyll $a$ in winter sample were $6.83 \mu \mathrm{g} \mathrm{cm}^{-2}$, while spring Chl $a$ was $68.31 \mathrm{\mu g} \mathrm{cm}^{-2}$.

\subsection{Diatom assemblage}

A total of 25 diatom species was recorded from samples at the Krčić Spring. A number of species was rather low and relatively constant (12-15). In every sample one or two species dominated, while other diatoms were poorly represented with only a few frustules. All samples were dominated by Achnanthidium minutissimum (Kützing) Czarnecki, with a very high abundance in winter $(92 \%)$, as well as in spring (35\%). During winter only Fragilaria capucina Desmazières, Meridion circulare (Greville) C.Agardh, Navicula cryptocephala Kützing and Nitzschia palea (Kützing) W.Smith had abundance greater than $0.5 \%$. The same species were also more abundant in the spring samples, with subdominant $N$. palea $(27 \%)$ and $M$. circulare $(22 \%)$.

\subsection{Morphological characterization of cyanobacterial taxa}

According to microscopic and morphological observations, dominant species in the microbial mat of the Krčić Spring in both winter and spring samples was Phormidium favosum Gomont (Fig. 3). The second most dominant species in the community was Hydrocoleum muscicola Hansgirg ex Forti. 

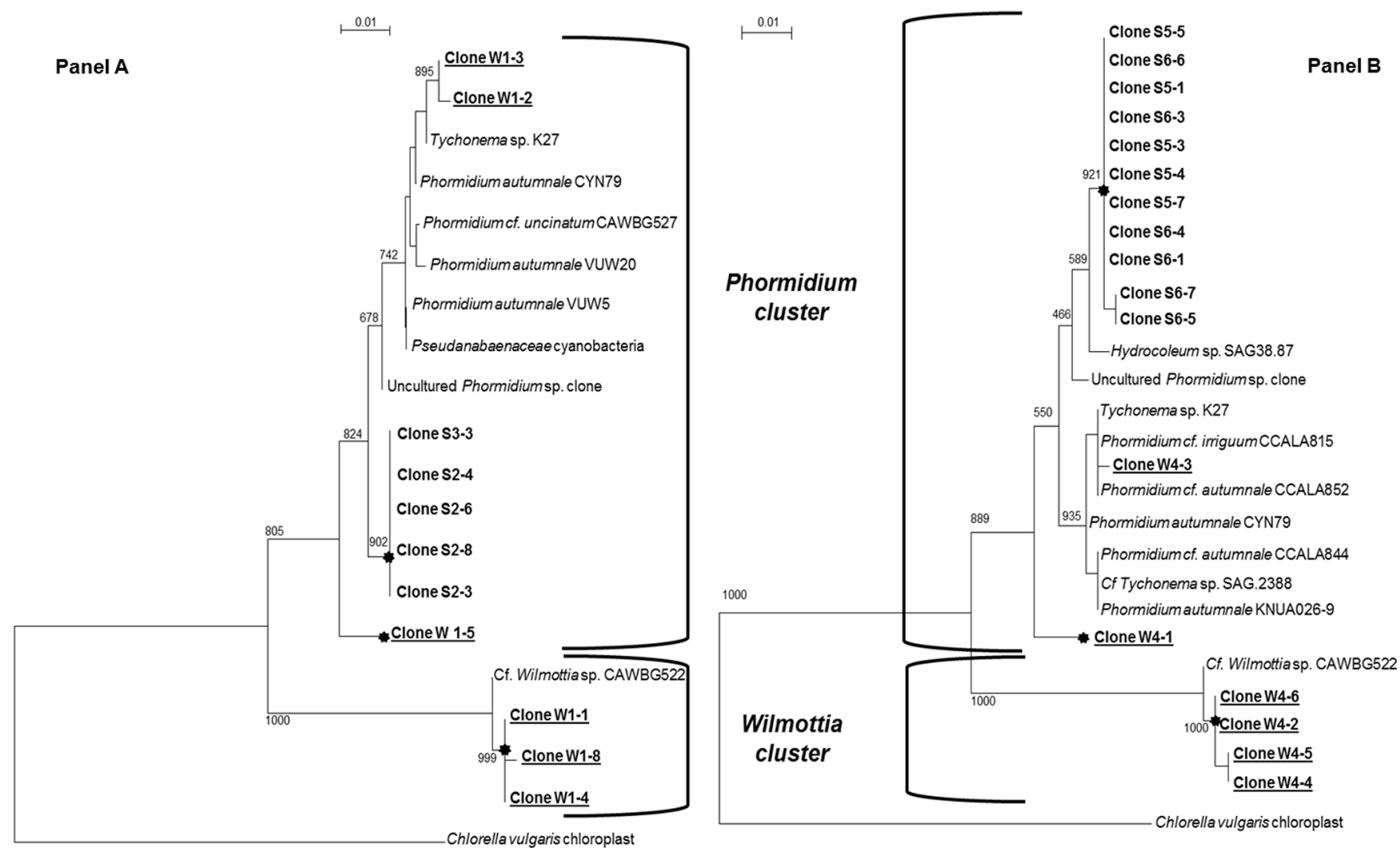

Fig. 4. Phylogenetic relationship of 16S rRNA larger fragment (A) and smaller fragment amplicon (B) amplified in clones originating from the Krčić Spring mat to the most related strains selected from GenBank database. Sequences obtained from the winter sample clone libraries are underlined and marked with "Clone W", while those from spring clone libraries with "Clone S". Sub-clusters are marked with asterisk. Molecular phylogenetic analyses were conducted in Clustal X2. The bootstrap consensus tree was inferred from 1000 replicates.

\subsection{Phormidium favosum Gomont}

Thallus blue-green, layered and soft. Trichomes bluegreen, narrow, curved at both ends, unconstricted at the cross walls. Apical cells well developed, capitate, with well-formed wall thickenings (calyptrae). Cells with distinct granules agglomerated at the cross walls. Cell width from 3.1 to $5.6 \mu \mathrm{m}$ (avg. $4.7 \mu \mathrm{m}$ ), length between 2.9 and $4.5 \mu \mathrm{m}$ (avg. $3.7 \mu \mathrm{m}$ ); cells only slightly wider than long (length/width ratio 1.3). Atypical morphotypes also present, with capitate and widely rounded apical cells.

\subsection{Hydrocoleum muscicola Hansgirg ex Forti}

Thallus light brown, soft, placed underneath blue-green layers of Phormidium. Sheaths thin, colourless, usually enclosing one or up to several trichomes. Trichomes pale green, 2.9-4.5 $\mu \mathrm{m}$ (avg. 3.4 $\mu \mathrm{m}$ ) wide. Cells 2.2-4.1 $\mu \mathrm{m}$ (avg. $3.2 \mu \mathrm{m}$ ) long, on average almost isodiametric (length/width ratio 1.1). Apical cells widely rounded, without calyptrae.

\subsection{Molecular phylogeny of cyanobacterial mats}

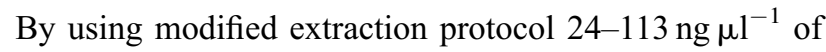
high-quality DNA was successfully obtained from cyanobacterial mats collected in the Krčić Spring at both winter and spring sampling times. PCR amplification of the cyanobacterial 16S rRNA gene gave amplicons of the expected sizes: (i) in 1st PCR larger fragment of $650 \mathrm{bp}$, and (ii) in 2nd PCR smaller fragment of $450 \mathrm{bp}$. After cloning into appropriate vector four separate clone libraries were established: (i) winter sample/ larger fragment, (ii) winter sample/smaller fragment, (iii) spring sample/larger fragment, and (iv) spring sample/smaller fragment. Clones were further subjected to RFLP analysis in order to check the diversity of cyanobacterial communities. Clones showing different restriction patterns were assembled into different RFLP families (results not presented). For further sequencing, at least one representative member of each of the RFLP family (altogether 28 clones) was chosen. Based on the sequences pairwise alignment phylogenetic tree was built (Fig. 4). Majority of sequences shared high homology (98$99 \%$ ) with the 16S rRNA gene of the Oscillatoriales genera Tychonema K. Anagnostidis and J. Komárek, Pseudanabaena Lauterborn and Hydrocoleum Kützing ex Gomont but mainly matched to Phormidium autumnale Gomont. Similarities between 16S rRNA sequences of these genera did not allow more clear identification of the species. A smaller number of sequences were identified as Wilmottia O. Strunecký, J. Elster and J. Komárek.

Analogous phylogenies were obtained by analysing both smaller and larger 16S rRNA gene fragments sequences (Fig. 4). Sequences clearly grouped into 2 separate clusters: (i) "Phormidium cluster", and (ii) "Wilmottia cluster", with the 

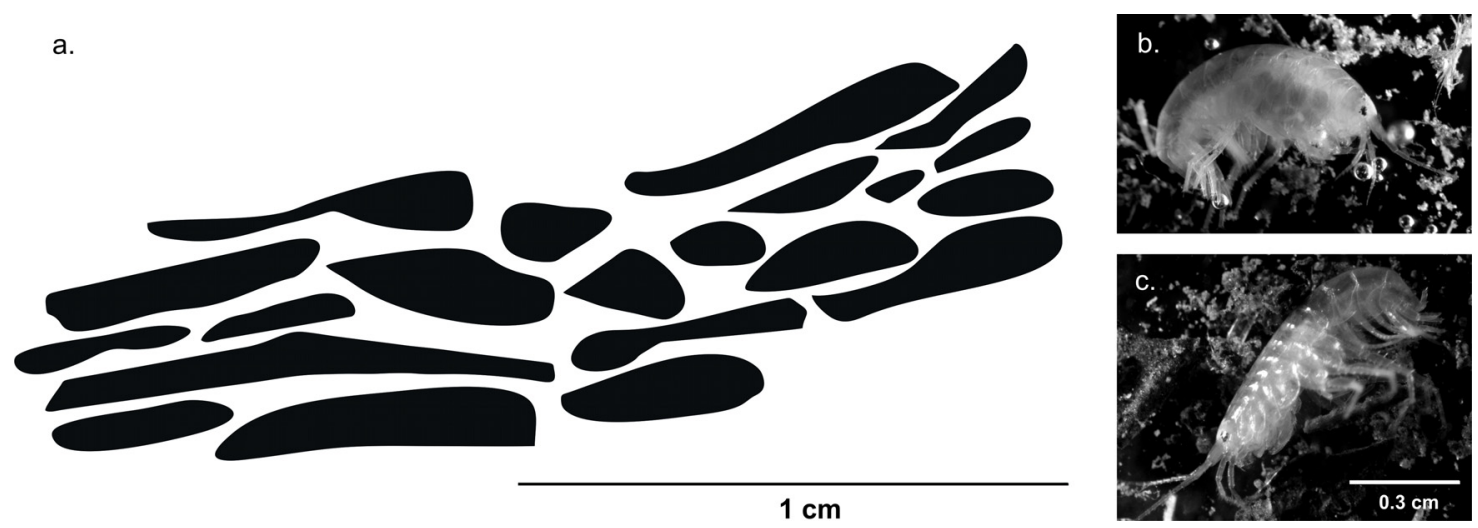

Fig. 5. Pockets of microbial mat, detailed scheme (a); Synurella ambulans (b) female specimen; (c) male specimen.

majority of sequences falling into "Phormidium cluster". Sequence comparison showed $7-10 \%$ difference in $16 \mathrm{~S}$ rRNA among the clusters, thus indicating a distinct phylogenetic separation. Cyanobacteria selected from the GenBank were shown to originate from geographically distinct regions, such as German, Spanish and Swedish streams, but also streams from New Zealand and Polar Regions. Phylogenetic tree revealed that the representatives of the "Phormidium cluster" could be found in the Krčić Spring in both spring (Clones S3-3, S2-4, S2-6, S2-8, S2-3, S5-5, S6-6, S5-1, S6-3, S5-3, S5-4, S5-7, S6-4, S6-1, S 6-7, S6-5) and winter (Clones W1-5, W1-3, W1-2, W4-1, W4-3) seasons. However, clones forming "Wilmottia cluster" originated exclusively from the sample collected at the winter time. These winter clones (clones W1-1, W1-8, W1-4, W4-6, W4-5 and W4-4) showed 99\% homology to Wilmottia sp. CAWBG522 isolated from benthic freshwater habitats in New Zealand. In addition to main clusters two sequences W1-5 (larger 16S rRNA fragment) and W4-1 (smaller 16S rRNA fragment, based on the $97 \%$ similarity cutoff value, formed distinct operational taxonomic units (OTUs) inside "Phormidium cluster".

\subsection{Microbial mat as a shelter for crustaceans}

Laboratory observations on fresh microbial mat revealed a small stygophilic amphipod species $S$. ambulans. The adult specimens were less than $7 \mathrm{~mm}$ in size, hiding and feeding on fine particulate organic matter (FPOM) inside the pockets of thin cyanobacteria-diatom jelly coating in size of cca $1-8 \mathrm{~mm}$ (Fig. 5). The average densities of crustaceans inside the pockets were presented in Table 2 .

\section{Discussion}

Recent studies on cyanobacterial representatives of lotic aquatic systems emphasize the problems of distinguishing cyanobacterial species based on morphological features and ecological preferences (Komárek, 2016), specifically referring to the Phormidium sensu lato group (Palińska and Marquardt, 2007; Strunecký et al., 2013). The classification of P. sensu lato by Komárek and Anagnostidis (2005) has recently been supplemented by several new genera based on the combination of both morphological and genetic features, namely the $16 \mathrm{~S}$
Table 2. Number of specimens of Synurella ambulans per square $10 \times 10 \mathrm{~cm}$ in mucilage microbial mat at the Krčić Spring.

\begin{tabular}{llll}
\hline Month & $\operatorname{Avg} \pm$ SD & Min & Max \\
\hline Winter (February 2014) & $6.75 \pm 4.50$ & 3 & 12 \\
Spring (May 2014) & $4.50 \pm 2.38$ & 2 & 7 \\
\hline
\end{tabular}

rRNA gene sequencing (Komárek, 2010; Strunecký et al., 2010; Chatchawan et al., 2012). P. autumnale Gomont, a key species within the complex, encompasses a cluster denominated as a group VII (Komárek and Anagnostidis, 2005), comprising species characterized by very similar morphological traits and widely diverse, ubiquitous morphotypes adapted to various biotopes (Strunecký et al., 2013). Subtle differences in colony formation, trichome organization and exploitation of distinct habitats can be noted amid the cluster.

Microbial mats predominately composed of $P$. autumnale complex prevail and dominate in fast flowing streams with rapid water current and stony bottom (Komárek et al., 2012), as was the case in the Krčić Spring. P. favosum, which is included into group VII, is attributed with isodiametric cells, trichomes shortly attenuated towards the trichome ends, and the presence of well-developed calyptrate apical cells. The ecotype-based differences between $P$. favosum and $P$. autumnale, where the former is a stenothermal species inhabiting cold oligotrophic streams and rivers (Strunecký et al., 2012), while the other is typical for meso- to eutrophic waters (Izaguirre et al., 2001; Palińska and Marquardt 2007; Strunecký et al., 2010; Hašler et al., 2012; Du, 2013; Loza et al., 2013) corresponded to morphological observations of species forming mats, as well as habitat characteristics of the Krčić Spring.

$P$. autumnale and other species within the group VII share similar features with the Microcoleus sensu stricto complex, $i$. $e$. homogeneous cell division and thylakoid structure, as noted by Boyer et al. (2002) and Komárek and Anagnostidis (2005). Consequent research on Microcoleus vaginatus and $P$. autumnale samples from different aquatic systems yielded a taxonomic revision of $P$. autumnale into Microcoleus autumnalis (Trevisan former Gomont) Strunecký, Komárek and Johansen comb. nov., and P. favosum into Microcoleus favosus (Gomont) Strunecký, Komárek and Johansen comb. 
nov. (Strunecký et al., 2013). Still, the taxonomic uncertainty of identifying morphospecies could produce spurious phylogenetic inferences (Bagley et al., 2015), specially when RNA sequencing of samples classified as $P$. autumnale indicates the presence of several different genotypes (Strunecký et al., 2013). Furthermore, when compared with the results of a partial 16S rRNA phylogeny, ecotype preferences used to separate $M$. vaginatus from $P$. autumnale proved fairly inaccurate. In addition, all subsequent taxonomic revisions of Microcoleus complex should include more genetic markers due to high similarity of the $16 \mathrm{~S}$ rRNA genes. Due to aforementioned reasons the authors have decided to use the nomenclature following the sequence names in the NCBI database.

As in the previous case, genera Microcoleus and Hydrocoleum are also morphologically poorly delineated. Although Komárek and Anagnostidis (2005) made distinctions based on the sheath structure, as being hyaline in Microcoleus opposed to lengthwise striated in Hydrocoleum, they stated that a phenotype with both features may appear, thus recommending a detailed molecular review in both genera.

H. muscicola is a freshwater species characterized by olive green to reddish, often warty thallus with trichomes 3-4 $\mu \mathrm{m}$ wide. According to Komárek and Anagnostidis (2005), it was reported from the hilly and mountainous streams in Austria (Carinthia, Tyrol) and Croatia (Dalmatia), and from tufa barrier waterfalls in Greece (Edessa, Macedonia). From the metaphyton samples collected in Nahuel Huapi National Park (Patagonia, Argentina) Wenzel and Díaz (2008) described following morphological characteristics of $H$. muscicola: trichomes unconstricted, roughly parallel, 3-4 $\mu \mathrm{m}$ in width, gradually attenuated at the ends; sheath hyaline, unbranched, narrow; cells $1.5-3 \mu \mathrm{m}$ in length, with granulations near the transverse walls; apical cells conical or rounded, sometimes capitated. This was in accordance with morphological observations on $H$. muscicola described herein, specifically the width of thalli, the size and structure of individual cells, and the shape of apical cells.

Results of the phylogenetic analysis confirmed presence of the Oscillatoriales cyanobacteria in the microbial mats of the Krčić Spring. Even though two different primers were used in order to elucidate cyanobacteria to the species level, cyanobacterial genera Phormidium, Hydrocoleum and Tychonema were not readily distinguished by their 16S rRNA gene sequences. These species showed high sequence similarity form a single clade with $80-90 \%$ bootstrap support, as was previously shown by Harland et al. (2014). Nevertheless, clear separation between two phylogenetically distinct clusters implied that two cyanobacterial populations dominate microbial mats in the Krčić Spring with clear seasonal differentiation. The Phormidium population, found in both winter and spring samples, supports characterization of dominant species appertaining to $\mathrm{P}$. autumnale complex. Other population comprised cyanobacteria identified as Wilmottia species. This finding was surprising since the cyanobacterial ribotypes corresponding to Wilmottia sp., to our knowledge, have not yet been reported in Croatia. Interestingly, this population was found exclusively in the winter sample. Ecology of Wilmottia species is considered to be very distinct, with low temperatures and long frozen periods. However, cyanobacteria isolated from cold environments have temperature optima growth rates in the range $15-20^{\circ} \mathrm{C}$, suggesting that they likely had their evolutionary origins within temperate latitudes (Jungblut et al., 2009), and only subsequently colonized perennial cold habitats. Considering this, Wilmottia in the Krčić Spring could be endemic for this area, although a broader investigation on the topic is needed for further conclusions. In addition, subclustering inside Phormidium population (clones W4-1, W1-5) indicated a possibile existence of cyanobacteria genotypes specific for Croatian region. Moreover, those strains were found to be exclusively related to winter season period.

$M$. circulare is a pennate araphid diatom with thickened silica ribs (costae) oriented transversely across the valve (Kociolek et al., 2011). It is a widely distributed member of benthic and periphytic (epilithic and epiphytic) communities of various freshwater ecosystems including brooks (Krejci and Lowe, 1987), streams (B-Béres et al., 2016), karstic springs and spring-fed streams (Cantonati and Ortler, 1998; Delgado et al., 2013) and alpine springs (Cantonati and Lange-Bertalot, 2010; Mogna et al., 2015). It forms fan-shaped colonies with cells enclosed within a mucilaginous polysaccharide matrix (Lock et al., 1984). Ecologically, M. circulare is classified as a crenophilic (Krammer and Lange-Bertalot, 1991a), alkaliphilous and oligo-eutraphentic species (Van Dam et al., 1994; Cantonati and Ortler, 1998), commonly present in calcareous medium-tohigh-altitude (500-1500 m a.s.1.) springs and streams (Margalef, 1949; Symoens, 1957). It is a microthermal species growing abundantly in the cold water within a temperature range of 7 $15^{\circ} \mathrm{C}$ (Whitford, 1960; Krejci and Lowe, 1987), with phosphorus-poor, high-light conditions (Cox, 1993; Hill et al., 2011), all of which conformed to the Krčić Spring.

As one of the most widely recognized freshwater diatoms, A. minutissimum, a species corresponding to a still largely unresolved species complex, is frequently dominating benthic algal communities in the upper courses of streams and rivers (Virtanen et al., 2011; Noga, 2012; Novais et al., 2015; Cyr, 2016). Despite its omnipresence and importance in water quality assessments, A. minutissimum is attributed to a rather difficult identification due to small cell size, inter- and intraspecific varieties and insufficiently studied ecology (Potapova and Ponader, 2004; Ponader and Potapova, 2007; Novais et al., 2015). It is an early colonizing species (Falasco et al., 2012) reported to successfully recolonize and develop dense populations in the fast water substrata after repeated annual dry phases (Della Bella et al., 2017). The properties of Krčić Spring corresponded to water associated with high abundance and frequency of $A$. minutissimum, like streamflow variability and slighty alkaline conditions (Noga et al., 2014; Della Bella et al., 2017; Jakovljević et al., 2016). A. minutissimum is reported as a pioneering species during the initial processes of biofilm formation (Sekar et al., 2004; Leinweber and Kroth, 2015). It is often the most numerous diatom occuring in $P$. autumnale and $P$. favosum-dominated microbial mats (Kelly, 2012; Brasell et al., 2015), as was the case in Krčić Spring, where it could efficiently utilise potency by forming pads and stalks, thus additionally anchoring the biofilm.

$N$. palea is a pennate diatom with the nitzschioid eccentically positioned raphe within a keel supported by fibulae (Spaulding and Edlund, 2008), lanceolate valves, barely visible striae with parallel sides and poles terminating with subcapitate apices (Kociolek et al., 2011). It is a benthic diatom with wide geographical distribution in freshwater lentic 
and lotic habitats (Trobajo et al., 2010). N. palea is a taxonomically problematic species encompassing a multitude of cryptic and pseudocryptic species into a $N$. palea complex (Trobajo et al., 2009). It is capable of surviving extreme environmental conditions prevailing in the Krčić Spring, like high streamflow variability and annual periods of drought, as was also noted in Australian dryland river systems (McGregor et al., 2006). N. palea was also found in tufa-forming microbial mats from the Harz Mountains karst streams in Germany (Arp et al., 2010). Due to its exceptional tolerance to organic pollution and heavy metals (Palmer, 1969), biomass increase of $N$. palea is an indication of anthropogenic pollution (Tornés et al., 2007; Bere et al., 2014). The low abundance of N. palea recorded in Krčić Spring during the study period suggests minimum anthropogenic pressure on the stream. In that regard, close monitoring of $N$. palea could provide valuable information of a possible increase of human-induced impacts on the extremely vulnerable karst environments (Trobajo et al., 2009; Delgado et al., 2012).

$N$. cryptocephala is a benthic solitary pennate diatom with symmetrical biraphid morphological features (Potapova, 2011). Although common in a multitude of freshwater habitats, this polymorphic diatom is comprised of a complex of pseudo-cryptic species with presumably restricted distributions (Poulíčková et al., 2010). It is a common member of metaphytic communities in well illuminated, alkaliphilous, lotic habitats with relatively low nutrient concentrations (Blinn and Bailey, 2001; Cox et al., 2011).

F. capucina is an araphid pennate diatom frequently noted in benthic assemblages (Tuji and Williams, 2006; Boulêtreau et al., 2010) with many recognized varieties. Although tolerant to increase in concentrations of heavy metals, it usually favours rheophilic, alkaliphilic habitats with lower water temperature, and low to moderate nutrient conditions (Kelly et al., 2005). The high abundance of $F$. capucina was recorded in several Croatian karst aquatic systems, like the karst stream Jankovac (Špoljar et al., 2012) and karst submountain river Lika (Mejdandžić et al., 2015). The most dominant epilithic taxa recorded in the Su Gologone karst spring in Italy were alkaliphilous, oligotrophic species, including $F$. capucina and $N$. cryptocephala (Lai et al., 2016). Delgado et al. (2012) have split diatom taxa from 60 Mediterranean temporary karst streams into two groups based on their sensitivity or tolerance. $F$. capucina and $N$. cryptocephala were placed into sensitive taxa indicating reference sites, while $N$. palea was grouped into tolerant taxa, in which case the abundance of species was referring to disturbance. Moreover, a study on the 371 streams from Portugal on both siliceous and carbonate (karst) bedrock (Feio et al., 2012) indicated that all three aforementioned diatoms preferred streams on non-siliceous substrate, with mean water temperature of $15^{\circ} \mathrm{C}$, increased hardness and alkalinity, and higher degree of temporality.

\subsection{Interspecies cohabitation on the edge}

Pockets of microbial mat in Krčić Spring serve as an important shelter for stygophilic amphipod $S$. ambulans when moss as the primary substratum is not fully developed. The cyanobacteria-diatom mat protects amphipods from drift, usually during the flow activation in autumn or from the Dinara mountain snowmelt in spring. Therefore, the amphipods are presumably well adapted to: (1) changing currents caused by seasonal drying of the spring, and (2) changing of living substrates.

The low dispersal ability of the stygophilous amphipod $S$. ambulans causes specific selection of offered substrates, such as microbial mat, within the relatively small scale of spring patches. Since the inhabitants of subterranean ecosystems might be poor competitors in more ecologically complex surface environments (Fišer et al., 2014), surface-dwelling species may limit the extant of the distribution of $S$. ambulans in pockets of the microbial mat in photic habitats. Moreover, the intermittent Krčić Spring as a predator-free (fishes) and competitor-free (epigean amphipods) ecosystem provides a spatiotemporal conformity between microbial mat and stygophilous amphipod. Furthermore, microbial mat provides a large surface for small biota in a relatively stable habitat transition of aquatic-terrestrial ecotones (Cantonati et al., 2016) and can serve as a capturer of organic matter between the stony substrate of the Krčić Spring. On the other hand, flow rate variability and successive community dynamic and competition between the microbial mat and moss community in intermittent spring could cause changes in the choice of neighbouring shelters by amphipods, choosing moss cushions at the top of the stony substrate as a more dominant organic substrate in the Krčić Spring.

\section{Conclusion}

Succession of cyanobacteria and diatoms causes shift in food web structure of intermittent springs, not only when the spring dry up or during the flow oscillation, but moreover as a consequence of evolutionary internal clock in species adapted to temporary environment. Microbial mat most likely uses chemical signals in intra- and inter- species communication about physico-chemical conditions of the environment, but the information flow could also come from animals such as crustaceans and aquatic plants, playing a significant role in the organization and function of superorganism structure such as microbial mat in intermittent springs.

A huge negative impact of global warming on temporary karstic streams may be critical for the survival of some isolated and rare species of cyanobacteria and diatoms, as well as some sophistically adapted aquatic invertebrates living on the ecotone between groundwater and surface water. Moreover, any disturbance across a wide range of spatiotemporal scale of the aquifer-spring-terrestrial system can change the community structure or even induce removal of species.

Acknowledgments. This research was supported by the projects MULTISEK (Multimetric evaluation of crenobiocoenosis) funded by the Environmental Protection and Energy Efficiency Fund (code: 351-01/13-01/108) and AQUAHEALTH (Aquatic microbial ecology as an indicator of the health status of the environment) funded by the Croatian Science Foundation (code: 3494$)$. We are very grateful to Ivica Barač for all of his help during the field trips, and to Igor Stanković (Central Water Management Laboratory, Hrvatske vode) for creating the map of investigated area. 


\section{References}

Andersen RA. 2005. Algal culturing techniques. London: Elsevier Academic Press, 596 p.

Arp G, Bissett A, Brinkmann N, Cousin S, Beer DD, Friedl T, Mohr KI, Neu TR, Reimer A, Shiraishi F, Stackebrandt E, Ziel B. 2010. Tufa-forming biofilms of German karstwater streams: microorganisms, exopolymers, hydrochemistry and calcification. Geol Soc Spec Publ 336: 83-118.

Bagley JC, Alda F, Breitman MF, Bermingham E, van den BEP, Johnson JB. 2015. Assessing species boundaries using multilocus species delimitation in a morphologically conserved group of neotropical freshwater fishes, the Poecilia sphenops species complex (Poeciliidae). PLoS One 10: e0121139.

Bauld J. 1984. Microbial mats in marginal marine environments: Shark Bay, Western Australia and Spencer Gulf, South Australia. In: Cohen Y, Castenholz RW, Halvorson HO, eds. Microbial mats: stromatolites. New York: Alan R. Liss Incorporated, pp. 39-58.

B-Béres V, Lukács Á, Török P, Kókai Z, Novák Z, T-Krasznai E, Tóthmérész B, Bácsi I. 2016. Combined eco-morphological functional groups are reliable indicators of colonisation processes of benthic diatom assemblages in a lowland stream. Ecol Indic 64: 31-38.

Bere T, Mangadze T, Mwedzi T. 2014. The application and testing of diatom-based indices of stream water quality in Chinhoyi Town, Zimbabwe. Water SA 40: 503-512.

Blinn DW, Bailey PCE. 2001. Land-use influence on stream water quality and diatom communities in Victoria, Australia: a response to secondary salinization. Hydrobiologia 466: 231-244.

Bonacci O. 1987. Karst hydrology - with special reference to the Dinaric Karst. Berlin: Springer, 184 p.

Bonacci O. 1993. Karst springs hydrographs as indicators of karst aquifers. Hydrol Sci J 38: 51-62.

Bonacci O. 2015. Karst hydrogeology/hydrology of dinaric chain and isles. Environ Earth Sci 74: 37-55.

Bonacci O, Jukić D, Ljubenkov I. 2006. Definition of catchment area in karst: case of the rivers Krčić and Krka, Croatia. Hydrol Sci J 51: 682-699.

Boulêtreau S, Sellali M, Elosegi A, Nicaise Y, Bercovitz Y, Moulin F, Eiff O, Sauvage S, Sánchez-Pérez J, Garabétian F. 2010. Temporal dynamics of river biofilm in constant flows: a case study in a riverside laboratory flume. Int Rev Hydrobiol 95: 156-170.

Boyer SL, Johansen JR, Flechtner VR, Howard GL. 2002. Phylogeny and genetic variance in terrestrial Microcoleus (Cyanophyceae) species based on sequence analysis of the 16S rRNA gene and associated 16s-23s ITS region. J Phycol 38: 1222-1235.

Brasell KA, Heath MW, Ryan KG, Wood SA. 2015. Successional change in microbial communities of benthic Phormidiumdominated biofilms. Microb Ecol 69: 254-266.

Camacho FA, Thacker RW. 2006. Amphipod herbivory on the freshwater cyanobacterium Lyngbya wollei: chemical stimulants and morphological defenses. Limnol Oceanogr 51: 1870-1875.

Camacho FA, Thacker RW. 2013. Predator cues alter habitat use by the amphipod Hyalella azteca (Saussure). Freshw Sci 32: 11481154.

Cantonati M, Lange-Bertalot H. 2010. Diatom biodiversity of springs in the Berchtesgaden National Park (north-eastern Alps, Germany), with the ecological and morphological characterization of two species new to science. Diatom Res 25: 251-280.

Cantonati M, Ortler K. 1998. Using spring biota of pristine mountain areas for long-term monitoring. In: Hydrology, Water Resources and Ecology in Headwaters, Proceedings of the HeadWater'98 Conference Held at Meran/Merano, Italy, April, IAHS Publ 248, 1998, pp. 379-385.

Cantonati M, Rott E, Spitale D, Angeli N, Komárek J. 2012. Are benthic algae related to spring types? Freshw Sci 31: 481-498.

Cantonati M, Komárek J, Montejano G. 2015. Cyanobacteria in ambient springs. Biodivers Conserv 24: 865-888.

Cantonati M, Segadelli S, Ogata K, Tran H, Sanders D, Gerecke R, Rott E, Filippini M, Gargini A, Celico F. 2016. A global review on ambient Limestone-Precipitating Springs (LPS): Hydrogeological setting, ecology, and conservation. Sci Total Environ 568: 624-637

Chatchawan T, Komárek J, Strunecký O, Šmarda J, Peerapornpisal Y. 2012. Oxynema, a new genus separated from the genus Phormidium (Cyanophyta). Cryptogam Algol 33: 41-59.

Cox EJ. 1993. Freshwater diatom ecology: developing an experimental approach as an aid to interpreting field data. Hydrobiologia 269: 447-452.

Cox EJ, Marxsen J, Horvath TG. 2011. Primary producers. In: Wagner R, Marxsen J, Zwick P, Cox EJ, eds. Central European stream ecosystems: the long term study of the Breitenbach. Weinheim: Wiley-VCH Verlag GmbH \& Co. KGaA, pp. 99-129.

Cyr H. 2016. Wind-driven thermocline movements affect the colonisation and growth of Achnanthidium minutissimum, a ubiquitous benthic diatom in lakes. Freshw Biol 61: 1655-1670.

Delgado C, Pardo I, García L. 2012. Diatom communities as indicators of ecological status in Mediterranean temporary streams (Balearic Islands, Spain). Ecol Indic 15: 131-139.

Delgado C, Ector L, Novais MH, Blanco S, Hoffmann L, Pardo I. 2013. Epilithic diatoms of springs and spring-fed streams in Majorca Island (Spain) with the description of a new diatom species Cymbopleura margalefii sp. nov. Fottea 13: 87-104.

Della BV, Padula R, Charavgis F, Cingolani A, Colangelo P. 2017. Mediterranean river biomonitoring in Central Italy: diatom biodiversity and characterization of communities. J Limnol 76: $1-49$.

Du XL. 2013. Cyanobacteria predominance in Alberta's eutrophic lakes linked to iron scavenging strategy that uses siderophores and toxins. In: Electronic thesis and dissertation repository, University of Western Ontario, London, Ontario, 117 p.

Elster J, Komárek O. 2003. Ecology of periphyton in a meltwater stream ecosystem in the maritime Antarctic. Antarct Sci 15: 189201.

Esposito RMM, Horn SL, McKnight DM, Cox MJ, Grant MC, Spaulding SA, Doran PT, Cozzetto KD. 2006. Antarctic climate cooling and response of diatoms in glacial meltwater streams. Geophys Res Lett 33: L07406.

Falasco E, Ector L, Ciaccio E, Hoffmann L, Bona F. 2012. Alpine freshwater ecosystems in a protected area: a source of diatom diversity. Hydrobiologia 695: 233-251.

Feio MJ, Aguiar FC, Almeida SFP, Ferreira MT. 2012. AQUAFLORA: a predictive model based on diatoms and macrophytes for streams water quality assessment. Ecol Indic 18: 586-598.

Fiorillo F, Petitta M, Preziosi E, Rusi S, Esposito L, Tallini M. 2015. Long-term trend and fluctuations of karst spring discharge in a Mediterranean area (central-southern Italy). Environ Earth Sci 74: 153-172.

Fišer C, Pipan T, Culver DC. 2014. The vertical extent of groundwater metazoans: an ecological and evolutionary perspective. BioScience 64: 971-979.

Gooseff MN, McKnight DM, Runkel RL, Duff JH. 2004. Denitrification and hydrologic transient storage in a glacial 
meltwater stream, McMurdo Dry Valleys, Antarctica. Limnol Oceanogr 49: 1884-1895.

Hajna N, Mihevc A, Pruner P, Bosàk P. 2010. Palaeomagnetic research on karst sediments in Slovenia. Int J Speleol 39: 47-60.

Hao Y, Liu G, Li H, Li Z, Zhao JJ, Yeh T-C. 2012. Investigation of karstic hydrological processes of Niangziguan Springs (North China) using wavelet analysis. Hydrol Processes 26: 3062-3069.

Harland F, Wood S, Broady P, Gaw S, Williamson W. 2014. Polyphasic studies of cyanobacterial strains isolated from benthic freshwater mats in Canterbury, New Zealand. $N Z J$ Bot 52: $116-135$.

Hašler P, Dvořák P, Johansen JR, Kitner M, Ondřej V, Pouličková A. 2012. Morphological and molecular study of epipelic filamentous genera Phormidium, Microcoleus and Geitlerinema (Oscillatoriales, Cyanophyta/Cyanobacteria). Fottea 12: 341-356.

Hendey NI. 1964. An introductory account of the smaller algae of British coastal waters. Part V: Bacillariophyceae (Diatoms). Fishery investigations, Series IV. London: Her Majesty's Stationery Office $317 \mathrm{p}$.

Hill WR, Roberts BJ, Francoeur SN, Fanta SE. 2011. Resource synergy in stream periphyton communities. $J$ Ecol 99: 454-463.

Hofmann G, Werum M, Lange-Bertalot H. 2013. Diatomeen im Süßwasser - Benthos von Mitteleuropa. Bestimmungsflora Kieselalgen für die ökologische Praxis, 2nd ed. Königstein: Koeltz Scientific Books, 908 p.

Izaguirre I, Mataloni G, Allende L, Vinocur A. 2001. Summer fluctuations of microbial planktonic communities in a eutrophic lake-Cierva Point, Antarctica. J Plankton Res 23: 1095-1109.

Jakovljević OS, Popović SS, Vidaković DP, Stojanović KZ, Krizmanić JŽ. 2016. The application of benthic diatoms in water quality assessment (Mlava River, Serbia). Acta Bot Croat 75: 199-205.

Jukić D, Denić-Jukić V. 2006. Nonlinear kernel functions for karst aquifers. J Hydrol 328: 360-374.

Jungblut AD, Lovejoy C, Vincent WF. 2009. Global distribution of cyanobacterial ecotypes in the cold biosphere. ISME J 4: 191-202.

Kelly M. 2012. The semiotics of slime: visual representation of phytobenthos as an aid to understanding ecological status. Freshw Rev 5: 105-119.

Kelly MG, Bennion H, Cox EJ, Goldsmith B, Jamieson J, Juggins S, Mann DG, Telford RJ. 2005. Common freshwater diatoms of Britain and Ireland: an interactive key. Bristol: Environment Agency, CD-ROM.

Kociolek JP, Liu Y, Wang Q. 2011. Internal valves in populations of Meridion circulare from the A'er Mountain region of northeastern China: implications for taxonomy and systematics. J Syst Evol 49: 486-494.

Komárek J. 2010. Recent changes in cyanobacteria taxonomy based on a combination of molecular background with phenotype and ecological consequences (genus and species concept). Hydrobiologia 639: 245-259.

Komárek J. 2016. A polyphasic approach for the taxonomy of cyanobacteria: principles and applications. Eur J Phycol 51: 346-353.

Komárek J, Anagnostidis K. 2005. Süsswasserflora von Mitteleuropa 19/2. Cyanoprokaryota, 2. Teil: Oscillatoriales. Heidelberg: Elsevier Spektrum Akademischer Verlag, 759 p.

Komárek J, Nedbalová L, Hauer T. 2012. Phylogenetic position and taxonomy of three heterocytous cyanobacteria dominating the littoral of deglaciated lakes, James Ross Island, Antarctica. Polar Biol 35: 759-774.
Konrad CP, Brasher AMD, May JT. 2008. Assessing streamflow characteristics as limiting factors on benthic invertebrate assemblages in streams across the western United States. Freshw Biol 53: 1983-1998.

Korpinen S, Karjalainen M, Viitasalo M. 2006. Effects of cyanobacteria on survival and reproduction of the littoral crustacean Gammarus zaddachi (Amphipoda). Hydrobiologia 559: 285-295.

Krammer K, Lange-Bertalot H. 1986. Bacillariophyceae. 1. Teil: Naviculaceae. In: Ettl H, Gerloff J, Heynig H, Mollenhauer D, eds. Süsswasser flora von Mitteleuropa, Band 2/1. Stuttgart, New York: Gustav Fischer Verlag, 1-876.

Krammer K, Lange-Bertalot H. 1991a: Bacillariophyceae. 3. Teil: Centrales, Fragilariaceae, Eunotiaceae. In: Ettl H, Gerloff J, Heynig H, Mollenhauer D, eds. Süsswasserflora von Mitteleuropa, Band 2/3. Stuttgart, Jena: Gustav Fischer Verlag, 1-576.

Krammer K, Lange-Bertalot H. 1991b. Bacillariophyceae. 4. Teil: Achnanthaceae, Kritische Ergänzungen zu Navicula (Lineolatae) und Gomphonema, Gesamtliteraturverzeichnis Teil 1-4. In: Ettl H, Gärtner G, Gerloff J, Heynig H, Mollenhauer D, eds. Süsswasserflora von Mitteleuropa, Band 2/4. Stuttgart, Jena: Gustav Fischer Verlag, 1-437.

Krejci ME, Lowe RL. 1987. The seasonal occurrence of macroscopic colonies of Meridion circulare (Bacillariophyceae) in a spring-fed brook. Trans Am Microsc Soc 106: 173-178.

Lai GG, Padedda BM, Wetzel CE, Lugliè A, Sechi N, Ector L. 2016. Epilithic diatom assemblages and environmental quality of the $\mathrm{Su}$ Gologone karst spring (centraleastern Sardinia, Italy). Acta Bot Croat 75: 129-143.

Lange-Bertalot H. 2001. Diatoms of Europe, Volume 2: Navicula sensu stricto, 10 genera separated from Navicula sensu lato, Frustulia. In: Lange-Bertalot H, ed. Diatoms of the European inland waters and comparable habitats, A.R.G. Königstein: Gantner Verlag Komanditgesellschaft, pp. 1-526.

Larkin MA, Blackshields G, Brown NP, Chenna R, McGettigan PA, McWilliam H, Valentin F, Wallace IM, Wilm A, Lopez R, Thompson JD, Gibson TJ, Higgins DG. 2007. Clustal W and Clustal X version 2.0. Bioinformatics 23: 2947-2948.

Leinweber K, Kroth PG. 2015. Capsules of the diatom Achnanthidium minutissimum arise from fibrillar precursors and foster attachment of bacteria. PeerJ 3: e858.

Lévesque D, Cattaneo A, Hudon C. 2015. Benthic cyanobacterial mats serve as a refuge and food for the amphipod Gammarus fasciatus. Hydrobiologia 758: 171-181.

Lock MA, Wallace RR, Costerton JW, Charlton SE. 1984. River epilithon: Toward a structural-functional model. Oikos 42: 10-22.

Loza V, Perona E, Mateo P. 2013. Molecular fingerprinting of cyanobacteria from river biofilms as a water quality monitoring tool. Appl Environ Microbiol 79: 1459-1472.

Margalef R. 1949. Une nouvelle méthode limnologique pour l'étude du périphyton. Verh Internat Verein Theor Angew Limnol 10: 284-285.

McDonough OT, Hosen JD, Palmer MA. 2011. Temporary streams: the hydrology, geography, and ecology of non-perennially flowing waters. In: Elliott HS, Martin LE, eds. River ecosystems: dynamics, management and conservation. New York: Nova Science Publishers, 259-289.

McGregor GB, Marshall JC, Thoms MC. 2006. Spatial and temporal variation in algal-assemblage structure in isolated dryland river waterholes, Cooper Creek and Warrego River, Australia. Mar Freshwater Res 57: 453-466. 
McKnight DM, Runkel RL, Tate CM, Duff JH, Moorhead DL. 2004. Inorganic $\mathrm{N}$ and $\mathrm{P}$ dynamics of Antarctic glacial meltwater streams as controlled by hyporheic exchange and benthic autotrophic communities. $J$ North Am Benthol Soc 23: 171-188.

Mejdandžić M, Malešević N, Nemet M, Kralj Borojević K, Gligora Udovič M. 2015. Phytoplankton and phytobenthos as biological quality elements along karstic river. In: Abstracts of the 9th central European diatom meeting. Bremerhaven: Alfred Wegener Institute, pp. $58-58$.

Meyer A, Meyer EI. 2000. Discharge regime and the effect of drying on macroinvertebrate communities in a temporary karst stream in East Westphalia (Germany). Aquat Sci 62: 216-231.

Meyer A, Meyer EI, Meyer C. 2003. Lotic communities of two small temporary karstic stream systems (East Westphalia, Germany) along a longitudinal gradient of hydrological intermittency. Limnologica 33: 271-279.

Mogna M, Cantonati M, Andreucci F, Angeli N, Berta G, Miserere L. 2015. Diatom communities and vegetation of springs in the southwestern Alps. Acta Bot Croat 74: 265-285.

Mueller DR, Vincent WF. 2006. Microbial habitat dynamics and ablation control on the Ward Hunt Ice Shelf. Hydrol Process 20: $857-876$.

Noga T. 2012. Diversity of diatom communities in the Wisłok River (SE Poland). In: Wołowski K, Kaczmarska I, Ehrman JM, Wojtal AZ, eds. Phycological reports: current advances in algal taxonomy and its applications: phylogenetic, ecological and applied perspective. Krakow: Institute of Botany Polish Academy of Sciences, 109-128.

Noga T, Kochman N, Peszek Ł, Stanek-Tarkowska J, Pajączek A. 2014. Diatoms (Bacillariophyceae) in rivers and streams and on cultivated soils of the Podkarpacie region in the years 2007-2011. $J$ Ecol Eng 15: 6-25.

Novais MH, Jüttner I, Van der VB, Morais MM, Hoffmann L, Ector L. 2015. Morphological variability within the Achnanthidium minutissimum species complex (Bacillariophyta): comparison between the type material of Achnanthes minutissima and related taxa, and new freshwater Achnanthidium species from Portugal. Phytotaxa 224: 101-139.

Nübel U, Garcia-Pichel F, Muyzer G. 1997. PCR primers to amplify 16S rRNA genes from cyanobacteria. Appl Environ Microbiol 63: $3327-3332$

Palińska KA, Deventer B, Hariri K, Łotocka M. 2011. A taxonomic study on Phormidium-group (Cyanobacteria) based on morphology, pigments, RAPD molecular markers and RFLP analysis of the 16S rRNA gene fragment. Fottea 11: 41-55.

Palińska KA, Marquardt J. 2007. Genotypic and phenotypic analysis of strains assigned to the widespread cyanobacterial morphospecies Phormidium autumnale (Oscillatoriales). Arch Microbiol 189: 325-335.

Palmer CM. 1969. A composite rating of algae tolerating organic pollution. J Phycol 5: 78-82.

Perrière G, Gouy M. 1996. WWW-query: an on-line retrieval system for biological sequence banks. Biochimie 78: 364-369.

Ponader KC, Potapova MG. 2007. Diatoms from the genus Achnanthidium in flowing waters of the Appalachian Mountains (North America): Ecology, distribution and taxonomic notes. Limnologica 37: 227-241.

Potapova M. 2011. Navicula cryptocephala. http://westerndiatoms. colorado.edu/taxa/species/navicula_cryptocephala

Potapova MG, Ponader KC. 2004. Two common North American diatoms, Achnanthidium rivulare sp. nov. and A. deflexum (Reimer) Kingston: morphology, ecology and comparison with related species. Diatom Res 19: 33-57.
Poulíčková A, Veselá J, Neustupa J, Škaloud P. 2010. Pseudocryptic diversity versus cosmopolitanism in diatoms: a case study on Navicula cryptocephala Kütz. (Bacillariophyceae) and morphologically similar taxa. Protist 161: 353-369.

Reiss M, Chifflard P. 2015. Hydromorphology and biodiversity in headwaters: an eco-faunistic substrate preference assessment in Forest Springs of the German Subdued Mountains. In: Lo Y-H, Blanco JA, Roy S, eds. Biodiversity in Ecosystems - Linking Structure and Function. Rijeka: InTech, 223-258.

Robson BJ, Chester ET, Austin CM. 2011. Why life history information matters: drought refuges and macroinvertebrate persistence in non-perennial streams subject to a drier climate. Mar Freshw Res 62: 801-810.

Sekar R, Venugopalan VP, Nandakumar K, Nair KVK, Rao VNR. 2004. Early stages of biofilm succession in a lentic freshwater environment. Hydrobiologia 512: 97-108.

Spaulding S, Edlund MB. 2008. Fragilaria [WWW Document]. Diatoms U. S. http://westerndiatoms.colorado.edu/taxa/genus/ Fragilaria.

Špoljar M, Dražina T, Šargač J, Borojević KK, Žutinić P. 2012. Submerged macrophytes as a habitat for zooplankton development in two reservoirs of a flow-through system (Papuk Nature Park, Croatia). Ann Limnol 48: 161-175.

Srivastava R, Roseti D, Sharma AK. 2007. The evaluation of microbial diversity in a vegetable based cropping system under organic farming practices. Appl Soil Ecol 36: 116-123, https://doi. org/10.1016/j.apsoil.2007.01.008.

Stal LJ. 2012. Cyanobacterial mats and stromatolites. In: Whitton BA, ed. Ecology of Cyanobacteria II. Netherlands: Springer, 65-125.

Stal LJ, Caumette P. 1994. Microbial mats: structure, development and environmental significance. Berlin, Heidelberg: Springer, 463 p.

Stanish LF, O'Neill SP, Gonzalez A, Legg TM, Knelman J, McKnight DM,Spaulding S, Nemergut DR. 2013. Bacteria and diatom cooccurrence patterns in microbial mats from polar desert streams. Environ Microbiol 15: 1115-1131. DOI: 10.1111/ j.1462-2920.2012.02872.x

Strunecký O, Elster J, Komárek J. 2010. Phylogenetic relationships between geographically separate Phormidium cyanobacteria: is there a link between north and south polar regions? Polar Biol 33: $1419-1428$.

Strunecký O, Elster J, Komárek J. 2012. Molecular clock evidence for survival of Antarctic cyanobacteria (Oscillatoriales, Phormidium autumnale) from Paleozoic times. FEMS Microbiol Ecol 82: 482490.

Strunecký O, Komárek J, Johansen J, Lukešová A, Elster J. 2013. Molecular and morphological criteria for revision of the genus Microcoleus (Oscillatoriales, Cyanobacteria). J Phycol 49: 11671180.

Symoens JJ. 1957. Les eaux douces de l'Ardenne et des regions voisines: Les milieux et leur vegetation algale. Bull Soc R Bot Belg 84: 111-314.

Tornés E, Cambra J, Gomà J, Leira M, Ortiz R, Sabater S. 2007. Indicator taxa of benthic diatom communities: a case study in Mediterranean streams. Ann Limnol Int J Lim 43: 1-11.

Trobajo R, Clavero E, Chepurnov VA, Sabbe K, Mann DG, Ishihara S, Cox EJ. 2009. Morphological, genetic and mating diversity within the widespread bioindicator Nitzschia palea (Bacillariophyceae). Phycologia 48: 443-459.

Trobajo R, Mann DG, Clavero E, Evans KM, Vanormelingen P, McGregor RC. 2010. The use of partial cox1, rbcL and LSU rDNA sequences for phylogenetics and species identification within the Nitzschia palea species complex (Bacillariophyceae). Eur J Phycol 45: 413-425. 
Tuji A, Williams DM. 2006. Examination of the type material of Synedra rumpens=Fragilaria rumpens, Bacillariophyceae. Phycol Res 54: 99-103.

Van Dam H, Mertens A, Sinkeldam J. 1994. A coded checklist and ecological indicator values of freshwater diatoms from The Netherlands. Neth J Aquat Ecol 28: 117-133.

Virtanen LK, Köngäs P, Aitto-Oja S, Soininen J. 2011. Is temporal occurrence of diatoms related to species traits, local abundance, and regional distribution? J Phycol 47: 1445-1453.
Wenzel MT, Díaz MM. 2008. Cyanophyta del Parque Nacional Nahuel Huapi (Argentina), II. Darwiniana nueva serie 46: 5165.

Whitford LA. 1960. Ecological distribution of fresh-water algae. In: Tryon CA,Hartman RT, eds. The ecology of algae: a symposium held at the Pymatuning Laboratory of Field Biology on June 18 and 19, 1959, Pymatuning Laboratory of Field Biology. University of Pittsburgh. Ann Arbor, Michigan: Edwards Brothers Inc., 112 p.

Cite this article as: Žutinić P, Petrić I, Gottstein S, Gligora Udovič M, Kralj Borojević K, Kamberović J, Kolda A, Plenković-Moraj A, Ternjej I. 2018. Microbial mats as shelter microhabitat for amphipods in an intermittent karstic spring. Knowl. Manag. Aquat. Ecosyst., 419,7 . 